NBER WORKING PAPER SERIES

\title{
INTERNATIONAL PORTFOLIOS WITH SUPPLY, DEMAND AND REDISTRIBUTIVE SHOCKS
}

\author{
Nicolas Coeurdacier \\ Robert Kollmann \\ Philippe Martin \\ Working Paper 13424 \\ http://www.nber.org/papers/w13424
}

\author{
NATIONAL BUREAU OF ECONOMIC RESEARCH \\ 1050 Massachusetts Avenue \\ Cambridge, MA 02138 \\ September 2007
}

This paper has been prepared for the NBER International Seminar on Macroeconomics (ISOM) conference (June 2007). We thank Francesco Giavazzi, Fabio Ghironi and Refet Gurkaynak for their advice. For useful discussions and suggestions, we are also grateful to Alan Sutherland, Cédric Tille, and to workshop participants at University of Leuven, the Bundesbank, the ECB, the Konstanz Seminar on Monetary Theory and Policy, and at the Annual Meeting of the Society for Economic Dynamics. The authors are affiliated with CEPR. Robert Kollmann is also affiliated with Universite Paris XII; he thanks ECARES and the Belgian National Bank for financial support. Philippe Martin thanks Institut Universitaire de France for financial support. Correspondance to: Robert Kollmann, ECARES, Université Libre de Bruxelles, CP 114, 50 Av Franklin D. Roosevelt, B-1050 Brussels, Belgium. Authors' e-mail addresses: ncoeurdacier@london.edu, robert_kollmann@yahoo.com, philippe.martin@univ-paris1.fr. The views expressed herein are those of the author(s) and do not necessarily reflect the views of the National Bureau of Economic Research.

(C) 2007 by Nicolas Coeurdacier, Robert Kollmann, and Philippe Martin. All rights reserved. Short sections of text, not to exceed two paragraphs, may be quoted without explicit permission provided that full credit, including $\odot$ notice, is given to the source. 
International Portfolios with Supply, Demand and Redistributive Shocks

Nicolas Coeurdacier, Robert Kollmann, and Philippe Martin

NBER Working Paper No. 13424

September 2007

JEL No. F30,F41,G11

\begin{abstract}
This paper explains three key stylized facts observed in industrialized countries: 1) portfolio holdings are biased towards local equity; 2) international portfolios are long in foreign currency assets and short in domestic currency; 3 ) the depreciation of a country's exchange rate is associated with a net external capital gain, i.e. with a positive wealth transfer from the rest of the world. We present a two-country, two-good model with trade in stocks and bonds, and three types of disturbances: shocks to endowments, to the relative demand for home vs. foreign goods, and to the distribution of income between labor and capital. With these shocks, optimal international portfolios are shown to be consistent with the stylized facts.

Nicolas Coeurdacier

Department of Economics

London Business School

Regent's Park

London, NW1 4SA

United Kingdom

ncoeurdacier@london.edu

Robert Kollmann

ECARES

Université Libre de Bruxelles

50, Avenue Franklin D. Roosevelt

CP 114

B-1050 Brussels

Belgium

robert_kollmann@yahoo.com

Philippe Martin

Paris School of Economics

Université Paris 1 Panthéon Sorbonne

106-112 bd de l'Hopital

75013 Paris

France

philippe.martin@univ-paris1.fr
\end{abstract}




\section{Introduction}

In the past twenty years, international capital flows have increased to unprecedented levels, for both bonds and stocks. Gross external financial positions now exceed 100\% of GDP for major industrialized countries, so that variations in exchange rates and asset returns may generate sizable wealth transfers between countries. For industrialized countries, international portfolios are long in foreign currency and short in domestic currency, so that the depreciation of a country's exchange rate generates a net external capital gain, i.e. a positive wealth transfer from the rest of the world. Strikingly, though, home bias in equity portfolios remains sizable, despite the fact that most legal and technological impediments to international trade in assets have been eliminated, among industrialized countries. Lane and MilesiFerretti (2003, 2005, 2006a,b), Tille (2005), Gourinchas and Rey (2005) and Lane and Shambaugh (2007) have recently documented these facts (see also Tables A1 and A2 in the Appendix).

The goal of this paper is to explain these facts. For this purpose, a general equilibrium model with two countries (Home and Foreign) and two goods is used. There is international trade in Home and Foreign stocks and bonds. The model assumes consumption home bias, in accordance with the fact that the bulk of consumption consists of local goods. Three exogenous disturbances are assumed: shocks to endowments, to the distribution of income between labor and capital ('redistributive shocks'), and to the relative world demand for Home vs. Foreign goods. The relative demand shocks can reflect changes in preferences or in the quality or number of varieties of Home/Foreign goods.

Existing models of portfolio choice are generally unable to explain the international portfolio facts. We argue that one of the main reasons for this is that the prior literature has focused on supply shocks. When faced with a negative supply shock in the Home country - which triggers a Home real exchange rate appreciation - the optimal portfolio should generate an increase in Home net external financial income, in order to finance an increase in Home net imports and thus stabilize Home consumption. With just supply shocks, the optimal Home portfolio is hence biased towards Foreign equity: Foreign equity is a better hedge for Home output shocks than Home equity (the Foreign equity return exceeds the Home equity return when Home output is low). Note also that a model with just supply shocks predicts that a country whose exchange rate appreciates experiences a capital gain on its external assets, i.e. a wealth transfer from the rest of the world; in practice, however, industrialized countries that experience an exchange rate 
appreciation suffer a capital loss on their external assets.

We show that the introduction of redistributive shocks and of relative demand shocks allows to generate equity home bias, and external "valuation effects" (effects of exchange rate and asset price fluctuations on external positions) that are broadly consistent with the empirical evidence. Contrary to most of the related literature, we allow for trade in two bonds, denominated in Home and Foreign goods, respectively. The financial market is (effectively) complete when there are just two types of shocks; the market is incomplete with the three simultaneous types of shocks.

Intuitively, a redistributive shock (a shock that increases dividends of domestic firms while reducing domestic labor income) can be hedged by holding stocks of local firms, the home bias observed in the data. We show that, given equity home bias, it is efficient for each agent to go long in foreign currency bonds and short in domestic currency bonds, in order to hedge relative demand shocks. For example, when faced with a negative relative demand shock for Home goods - which worsens Home terms of trade - a bond portfolio that is short in Home good bonds and long in Foreign good bonds generates an external capital gain for the Home household, which allows the Home country to stabilize its consumption, by allowing it to increase its imports. The optimal bond portfolio thus produces a wealth transfer towards the country that experiences a depreciation of its real exchange rate, which is in line with actual valuation effects (see discussion above). We show that a plausibly calibrated model with simultaneous supply, demand and redistributive shocks produces realistic equity and bond positions, and that it captures the external valuation effects observed for industrialized countries.

To our knowledge, this is the first model which analyzes international equity portfolio choices, in an incomplete markets setting. Interestingly, the assumption here that there are bonds denominated in local and in foreign goods helps to explain equity home bias, as terms of trade movements can be hedged by holding bonds. In our model, international risk sharing occurs both through equity and bond holdings.

In the next section, we review the related literature and point to differences with the present analysis. Section 3 describes the model set-up. Section 4 solves for optimal portfolios under complete markets. Section 5 considers incomplete markets; we provide closed-form solutions for portfolios under incomplete markets, using the method developed by Devereux and Sutherland (2006) and calibrate our model to analyze its quantitative properties. 


\section{Related literature}

Since the well-known paper of French and Poterba (1991) that documented equity home bias, various form of cross-country heterogeneity among investors have been analyzed, in order to explain international portfolio holdings. Indeed, without heterogeneity, all investors would, in equilibrium, hold the same portfolio of worldwide assets, and thus no bias towards local assets would exist (see Lewis (1999) for a survey). In the present paper, we abstract from barriers to international capital movements and assume that any investor can purchase any security without transaction costs. In other words, each investor faces the same investment opportunity set; this is, admittedly, a strong assumption but our result would be reinforced if we assumed costs of buying foreign securities ${ }^{1}$. However, we assume that consumers have a greater preference for the locally produced good than for the imported good (consumption home bias). Empirically, the bulk of consumption consists of locally produced goods (see Kollmann (2006b)). Consumption home bias implies that the (consumption-based) real exchange rate fluctuates in response to supply and demand shocks. A recent literature has discussed possible links between the financial and real home biases; in particular, Obstfeld and Rogoff (2000), have argued that consumption home bias (due to trade costs for goods) can solve the equity home bias puzzle.

Uppal (1993), Coeurdacier (2005), Kollmann (2006a,b) and Obstfeld (2006) study portfolio choice in models with consumption home bias; in those settings, there are just output shocks, and the only traded assets are domestic and foreign stocks. Those models can only generate equity home bias when the substitution elasticity between domestic and imported goods is (roughly speaking) smaller than unity. Intuitively, a country that receives a negative output shock experiences an improvement of its terms of trade; when the substitution elasticity between local and imported goods is low, then the terms of trade improvement is so strong that the return on local equity rises compared to the return on foreign equity; thus, local equity has a high (relative) return in states of the world in which the country's output is low; this makes holding local equity attractive, and induces investors to mainly invest their wealth in local stocks. By contrast, when the substitution elasticity exceeds unity, then the relative return on local equity drops, when local output falls, and hence foreign equity is a better hedge for output fluctuations. Hence, a model with just supply shocks only generates equity home bias under the condition that a negative

\footnotetext{
${ }^{1}$ See Martin and Rey (2004, 2006), Heathcote and Perri (2004), Coeurdacier and Guibaud (2005), Coeurdacier (2005), Tille and van Wincoop (2006).
} 
local output shock raises the relative return on local equity. Essentially, in such a model, equity home bias only arises when a country's relative equity return is highly positively correlated with its terms of trade (and, hence, with its real exchange rate). Yet, empirically, the correlation between relative equity returns and real exchange rate changes is close to zero (see van Wincoop and Warnock (2006)). Our model here reproduces this low correlation, yet it also generates realistic equity home bias. This is due to the fact that (as mentioned above) our model assumes trade in stocks and in two bonds, denominated in the home and the foreign goods, respectively ${ }^{2}$. In our setting, bonds are essentially used to hedge real exchange rate risk, a feature that we view as realistic. Moreover, we assume relative demand shocks and redistributive shocks, in addition to the more standard supply shocks. Those new shocks break the close link between terms of trade movements and relative equity returns.

Another strand of literature related to our paper analyzes the impact of non-tradable labor income on equity home bias. According to this literature, the presence of labor income either worsens the home bias in equities puzzle (Brainard and Tobin (1991), Baxter and Jermann (1997)) or helps explaining it (Bottazzi, Pesenti and van Wincoop (1996), Julliard (2002 and 2004), Engel and Matsumoto (2006)). In the models discussed by these authors, the composition of equity portfolios hinges on the correlation between equity returns and wages; as households seek to hedge their human capital risk, they only hold local equity if local stock returns are negatively correlated with labor income (Bottazzi, Pesenti and van Wincoop (1996), Engel and Matsumoto (2006)) $)^{3}$. In our paper, labor income and equity returns are partially disconnected due to redistributive shocks from labor to capital (or dividends). There are two main differences that set our paper apart from the existing theoretical literature on the role of labor income in international portfolio choice. First, as already mentioned, we allow for two differentiated (tradable) goods and two differentiated bonds ${ }^{4}$. Due to the availability of bonds, the direction of the equity bias is not pinned down by the correlation between equity returns and wages. This can produce drastically different equity portfolios compared to the existing literature. The intuition for our result can be simply exposed in a situation where there are only output (endowment) shocks and redistributive shocks. In that case, the model here predicts full equity home bias, for any stochastic structure of the two

\footnotetext{
${ }^{2}$ Pavlova and Rigobon (2004) also present a two country model with trade in stocks and in differentiated bonds, but they exclusively focus on complete markets, and do not analyze portfolio choices.

${ }^{3}$ Lustig and van Nieuwerburgh (2005) argue that, empirically, physical and human capital returns are negatively correlated

${ }^{4}$ Engel and Matsumoto (2006) also allow for trade in home and foreign bonds.
} 
types of shock; households fully hold the local equity to insure themselves against redistributive shocks. Output shocks are hedged using positions in Home and Foreign bonds, as supply shocks affect the return difference between the two bonds (by altering terms-of-trade).

A second difference is that while most existing theoretical models assume that an equity portfolio exists that perfectly mimics wage returns (a case of perfect spanning and complete markets), we here allow for market incompleteness. This is important because complete markets models counterfactually predict perfect correlation between the ratio of home to foreign marginal utilities of consumption and the real exchange rate (the well-known "consumption-real exchange rate anomaly"; see Kollmann (1991, 1995, 1996), Backus and Smith (1993)); as recently documented, by Corsetti, Dedola, Leduc (2007) and Benigno and Thoenissen (2006), the correlation between relative consumption and the real exchange is low in the data (see also Chari, Kehoe, McGrattan (2002)). While Corsetti, Dedola, Leduc (2007) (or Kollmann $(1995,1996))$ tackle the puzzle by restricting the menu of assets, we adopt here a different strategy by increasing the number of shocks to obtain incomplete markets.

The theoretical literature on external valuation effects is more recent and has focused on their impact on current account adjustment. See, for example, Tille (2005), Blanchard, Giavazzi and Sa (2005) and Ghironi, Lee and Rebucci (2006). Ghironi et al. (2006) have a richer dynamic business cycle model (with endogenous labor and production) than the present paper. However, they assume that international financial transactions are costly and restricted to stocks In their model, steady state equity portfolios are pinned down by costs to holding foreign stocks. By contrast, our model assumes trade in stocks and bonds in a frictionless financial market.

\section{Set-up of the model}

\subsection{Goods and preferences}

We consider a two-period $(t=0,1)$ endowment economy. There are two symmetric countries, Home $(H)$ and Foreign $(F)$, each with a representative household. Each country produces one good. There is no output (and no consumption) at $t=0$, but agents trade financial claims (stocks and bonds) at date 0 . In period 1 , country $i=H, F$ receives an exogenous endowment $y_{i}$ of good $i . E_{0}\left(y_{i}\right)=1$ holds for both countries, where $E_{0}$ is the conditional expectation operator, given date $t=0$ information. Once stochastic 
endowments are realized, households consume using their financial and labor incomes (see below).

The country $i$ household has these preferences:

$$
U_{i}=E_{0}\left[\frac{C_{i}^{1-\sigma}}{1-\sigma}\right]
$$

where $C_{i}$ is an aggregate consumption index in period 1 . Like much of the literature, we take the coefficient of relative risk aversion to be greater than unity: $\sigma>1 . C_{i}$, for $i=H, F$ is given by:

$$
\begin{aligned}
& C_{H}=\left[a^{1 / \phi}\left(\Psi_{H} c_{H}^{H}\right)^{(\phi-1) / \phi}+(1-a)^{1 / \phi}\left(\Psi_{F} c_{F}^{H}\right)^{(\phi-1) / \phi}\right]^{\phi /(\phi-1)} \\
& C_{F}=\left[a^{1 / \phi}\left(\Psi_{F} c_{F}^{F}\right)^{(\phi-1) / \phi}+(1-a)^{1 / \phi}\left(\Psi_{H} c_{H}^{F}\right)^{(\phi-1) / \phi}\right]^{\phi /(\phi-1)}
\end{aligned}
$$

where $c_{j}^{i}$ is country $i / s$ consumption of the good from country $j . \phi$ is the elasticity of substitution between the two goods. $\Psi_{i}, i=H, F$ with $E_{0}\left(\Psi_{i}\right)=1$ is an exogenous worldwide shocks to the (relative) preference for the country $i$ good. To be more illustrative we call this shock an "iPod shock". Note that the shock $\Psi_{i}$ can also have a more supply oriented interpretation, as a shock to the quality of good $i$. In a model with love for variety of the Dixit-Stiglitz type, the shock could also reflect a change in the number of differentiated good varieties produced by country $i$. Broda and Weinstein (2007) report that electronics, records and tapes is the product group that has the largest quality/new goods bias in the CPI. Hence, our choice of name.

We assume a preference bias for local goods, $\frac{1}{2}<a<1$. Note that in the special "Cobb-Douglas" case $(\phi=1), a$ is the share of consumption spending devoted to the local good.

The welfare based consumer price indices that correspond to these preferences are:

$$
\begin{aligned}
& P_{H}=\left[a\left(p_{H} / \Psi_{H}\right)^{1-\phi}+(1-a)\left(p_{F} / \Psi_{F}\right)^{1-\phi}\right]^{1 /(1-\phi)} \\
& P_{F}=\left[(1-a)\left(p_{H} / \Psi_{H}\right)^{1-\phi}+a\left(p_{F} / \Psi_{F}\right)^{1-\phi}\right]^{1 /(1-\phi)},
\end{aligned}
$$

where $p_{H}$ and $p_{F}$ are the prices of good $\mathrm{H}$ and $\mathrm{F}$, respectively. Note that the welfare based CPIs indices may differ from empirical CPIs, if the empirical measures do not capture changes in preferences (or in the quality/number of varieties).

Resource constraints are given by:

$$
\begin{aligned}
c_{H}^{H}+c_{H}^{F} & =y_{H} \\
c_{F}^{F}+c_{F}^{H} & =y_{F} .
\end{aligned}
$$


We denote Home terms of trade, i.e. the relative price of the Home good in terms of the Foreign good, by $q$ :

$$
q \equiv \frac{p_{H}}{p_{F}}
$$

\subsection{Financial markets}

There is trade in stocks and bonds, in period 0. Each stock represents a share in one of the future endowments. The supply of each type of share is normalized at unity. An exogenous fraction $k_{i}$ of the country $i$ endowment $y_{i}$ accrues to share holders, while a fraction $\left(1-k_{i}\right)$ is received by the local household. Hence, $\left(1-k_{i}\right) p_{i} y_{i}$ can be interpreted as country $i$ 'labor' income. There is a bond denominated in the Home good, and a bond denominated in the Foreign good. Buying one unit of the Home (Foreign) bond in period 0 gives one unit of the Home (Foreign) good at $t=1$. Both bonds are in zero net supply.

Each household fully owns the local stock, at birth, and has zero initial foreign assets. The country $i$ household thus faces the following budget constraint, at $t=0$ :

$$
p_{S} S_{i}^{i}+p_{S} S_{j}^{i}+b_{i}^{i}+b_{j}^{i}=p_{S}, \quad \text { with } j \neq i
$$

where $S_{j}^{i}$ is the number of shares of stock $j$ held by country $i$, at the end of period 0 , while $b_{j}^{i}$ represents claims (held by $i$ ) to future unconditional payments of good $j . p_{S}$ is the share price (identical for both stocks due to symmetry $)^{5}$.

Market clearing in asset markets requires: $S_{H}^{H}+S_{H}^{F}=S_{F}^{F}+S_{F}^{H}=1$ and $b_{H}^{H}+b_{H}^{F}=b_{F}^{F}+b_{F}^{H}=$ 0. Symmetry of preferences and shock distributions implies that equilibrium portfolios are symmetric: $S_{H}^{H}=S_{F}^{F}, S_{F}^{H}=S_{H}^{F}, b_{H}^{H}=b_{F}^{F}$ and $b_{F}^{H}=b_{H}^{F}$. In what follows, we denote a country's holdings of local stock by $S$, and its holdings of bonds denominated in its local good by $b$. The pair $(S ; b)$ thus describes portfolios. $S>\frac{1}{2}$ means that there is equity home bias; and $b<0$ means that a country issues bonds denominated in its local good, and that the country is lending in units of the foreign good.

Finally, we define a country's net foreign "currency" position (FCP) as its holdings of assets denominated in foreign good units, net of the country's liabilities denominated in foreign good. Up to a first-order approximation, $p_{S}=\bar{k}$ holds, where $\bar{k} \equiv E_{0}\left(k_{i}\right)$ is the expected capital share. Hence,

$$
F C P=\bar{k}(1-S)-b
$$

\footnotetext{
${ }^{5}$ Bond prices are also identical due to symmetry.
} 
Empirically, $F C P$ is positive for industrialized countries (as explained in the Introduction). Note that, in the model, FCP equals the expected payment of foreign "currency" (foreign good) received by a country, in period 1. Symmetry entails that if a country is long in foreign currency $(F C P>0)$, then the country has a short position of the same amount, in its own currency (good). A positive $F C P$ means that, ceteris paribus, a $1 \%$ worsening of a country's terms of trade $(q)$ generates an increase in the country's net external income that represents FCP \% of its expected GDP.

\section{Characterization of world equilibrium with complete markets}

To build up intuition, we first characterize the equilibrium with (effectively) complete markets (as shown below, markets are complete when the number of shocks equals the number of assets).

\subsection{Efficient consumption and terms-of-trade}

When markets are complete, the equilibrium allocation is Pareto efficient, so that it corresponds to the allocation chosen by a social planner who maximizes the sum of countries' utilities, subject to the resource constraints (6) and (7):

$$
\max _{\left\{c_{H}^{H}, c_{H}^{F}, c_{F}^{H}, c_{F}^{F}\right\}} \frac{C_{H}^{1-\sigma}}{1-\sigma}+\frac{C_{F}^{1-\sigma}}{1-\sigma}
$$

We obtain the following first order conditions for consumption:

$$
\begin{array}{lr}
c_{H}^{H}=a \Psi_{H}^{\phi-1} \lambda_{H}^{-\phi} C_{H}^{1-\sigma \phi} & c_{H}^{F}=(1-a) \Psi_{H}^{\phi-1} \lambda_{H}^{-\phi} C_{F}^{1-\sigma \phi} \\
c_{F}^{H}=(1-a) \Psi_{F}^{\phi-1} \lambda_{F}^{-\phi} C_{H}^{1-\sigma \phi} & c_{F}^{F}=a \Psi_{F}^{\phi-1} \lambda_{F}^{-\phi} C_{F}^{1-\sigma \phi}
\end{array}
$$

where $\lambda_{H}$ and $\lambda_{F}$ are the multipliers on the Home and Foreign market clearing conditions (6) and (7), respectively. The decentralized equilibrium is such that Home terms of trade $q \equiv \frac{p_{H}}{p_{F}}$ equal the ratio of multipliers: $\lambda_{H} / \lambda_{F}=q$ Hence, using the market clearing conditions (6) and (7), we get:

$$
\begin{aligned}
c_{H}^{H}+c_{H}^{F} & =\Psi_{H}^{\phi-1} p_{H}^{-\phi}\left[a C_{H}^{1-\sigma \phi}+(1-a) C_{F}^{1-\sigma \phi}\right]=y_{H} \\
c_{F}^{F}+c_{F}^{H} & =\Psi_{F}^{\phi-1} p_{F}^{-\phi}\left[a C_{F}^{1-\sigma \phi}+(1-a) C_{H}^{1-\sigma \phi}\right]=y_{F}
\end{aligned}
$$

Taking the ratio of these expressions and defining $\Omega(x)=\frac{1+x\left(\frac{1-a}{a}\right)}{x+\left(\frac{1-a}{a}\right)}$ gives:

$$
q^{-\phi}\left(\frac{\Psi_{H}}{\Psi_{F}}\right)^{\phi-1} \Omega\left[\left(\frac{C_{F}}{C_{H}}\right)^{1-\sigma \phi}\right]=\frac{y_{H}}{y_{F}}
$$


When markets are complete, the ratio of Home to Foreign marginal utilities of aggregate consumption is linked to the consumption-based real exchange rate by the following, familiar condition:

$$
\left(\frac{C_{H}}{C_{F}}\right)^{-\sigma}=\frac{P_{H}}{P_{F}}
$$

Hence, any shock that raises Home aggregate consumption relative to Foreign aggregate consumption must be associated with a Home real exchange rate depreciation. Thus, under complete markets:

$$
q^{-\phi}\left(\frac{\Psi_{H}}{\Psi_{F}}\right)^{\phi-1} \Omega\left[\left(\frac{P_{H}}{P_{F}}\right)^{\frac{1}{\sigma}-\phi}\right]=\frac{y_{H}}{y_{F}}
$$

\subsection{Budget constraints}

Recall that each household holds shares $S$ and $1-S$ of local and foreign stocks, respectively, while $b$ denotes her holding of bonds denominated in her local good; also, the stock $j$ dividend is $k_{j} p_{j} y_{j}$. The period 1 budget constraints of countries $H$ and $F$ are, thus:

$$
\begin{aligned}
P_{H} C_{H} & =S k_{H} p_{H} y_{H}+(1-S) k_{F} p_{F} y_{F}+p_{H} b-p_{F} b+\left(1-k_{H}\right) p_{H} y_{H} \\
P_{F} C_{F} & =(1-S) k_{H} p_{H} y_{H}+S k_{F} p_{F} y_{F}-p_{H} b+p_{F} b+\left(1-k_{F}\right) p_{F} y_{F}
\end{aligned}
$$

These constraints imply:

$$
P_{H} C_{H}-P_{F} C_{F}=(2 S-1)\left(k_{H} p_{H} y_{H}-k_{F} p_{F} y_{F}\right)+2 b\left(p_{H}-p_{F}\right)+\left(1-k_{H}\right) p_{H} y_{H}-\left(1-k_{F}\right) p_{F} y_{F}
$$

which says that the difference between countries' consumption spending equals the difference between their incomes.

\subsection{Log-linearization of the model}

Henceforth, we write $y \equiv \frac{y_{H}}{y_{F}}, \Psi \equiv \frac{\Psi_{H}}{\Psi_{F}}$ and $k \equiv \frac{k_{H}}{k_{F}}$ to denote relative outputs, preference shocks and capital shares. We log-linearize the model around the symmetric deterministic steady-state where $y, \Psi$ and $k$ equal unity, and use $\widehat{x} \equiv \log (x / \bar{x})$ to denote the log deviation of a variable $x$ from its steady state value $\bar{x}$.

The log-linearization of the Home country's welfare-based real exchange $R E R_{W B} \equiv \frac{P_{H}}{P_{F}}$ gives:

$$
R \widehat{E R_{W B}}=\frac{\widehat{P_{H}}}{P_{F}}=(2 a-1)(\widehat{q}-\widehat{\Psi})
$$


It is important to notice that the real exchange rate observed by the statistician might be different from the welfare-based real exchange rate since preference or quality changes are very imperfectly measured. We denote by $R E R$ the real exchange rate measure derived from CPI measures that do not capture taste or quality changes, so that: $\widehat{R E R}=(2 a-1) \widehat{q}$.

Log-linearizing (17) and (21) implies:

$$
\widehat{y}=-\left[\phi\left(1-(2 a-1)^{2}\right)+(2 a-1)^{2} \frac{1}{\sigma}\right](\widehat{q}-\widehat{\Psi})-\widehat{\Psi} \equiv-\lambda \widehat{q}+(\lambda-1) \widehat{\Psi}
$$

where $\lambda \equiv \phi\left(1-(2 a-1)^{2}\right)+\frac{(2 a-1)^{2}}{\sigma}$. Note that $\lambda>0$ as $1 / 2<a<1$.

It follows from (22), that the equilibrium relative price is:

$$
\widehat{q}=-\frac{1}{\lambda} \widehat{y}+\frac{\lambda-1}{\lambda} \widehat{\Psi}
$$

As expected, Home terms-of-trade $(q)$ are decreasing in relative Home output $\widehat{y}$ (with an elasticity $-\frac{1}{\lambda}$ ). Home terms of trade are increasing in the relative demand (iPod) shock $\Psi$ if and only if $\lambda>1$; roughly speaking, this is the case when the substitution elasticity between Home and Foreign goods, $\phi$, is larger than unity. The reason why the sign of the response of terms of trade to the relative iPod shock $\Psi$ depends on the substitution elasticity is the following: the relative supply of good $H$ in "efficiency" units is $\Psi y$, while the relative price of one efficiency unit of good $H$ (in efficiency units of good $F$ ) is $q / \Psi$. Hence, a positive relative iPod shock both induces an increase in the (relative) supply of good $\mathrm{H}$, in efficiency units, and an increase in demand. While the first effect reduces the relative price (not adjusted for efficiency units) with an elasticity of $\frac{1}{\lambda}$, the second effect increases the relative price with a unit elasticity. When demand is sufficiently elastic (so that $\lambda$ exceeds unity), then the demand effect dominates and the relative price (unadjusted for efficiency units) increases with the relative iPod shock.

We next log-linearize equation (20); using (21) and (16) we obtain:

$$
{\widehat{P_{H} C_{H}}}_{-P_{F} C_{F}}=\left(1-\frac{1}{\sigma}\right) \underbrace{(2 a-1)(\widehat{q}-\widehat{\Psi})}_{R E R_{W B}}=\bar{k}(2 S-1)(\widehat{q}+\widehat{k}+\widehat{y})+2 b \widehat{q}+(1-\bar{k})\left(\widehat{q}+\widehat{y}-\frac{\bar{k}}{1-\bar{k}} \widehat{k}\right)
$$

The first equality shows the Pareto optimal reaction of relative consumption spending to a change of the welfare based real exchange rate. This reaction depends on the coefficient of relative risk aversion. In a Pareto efficient equilibrium, a shock that appreciates the (welfare based) real exchange rate of country $H$, induces an increase in country $H$ relative consumption spending when $\sigma>1$ (as assumed in the 
analysis here). The risk-sharing condition (16) shows that when the (welfare based) real exchange rate appreciates by $1 \%$, then relative aggregate country $H$ consumption $\left(\frac{C_{H}}{C_{F}}\right)$ decreases by $1 / \sigma \%$. Hence, efficient relative consumption spending by $H\left(\frac{P_{H} C_{H}}{P_{F} C_{F}}\right)$ increases by $\left(1-\frac{1}{\sigma}\right) \%$. The expression to the right of the second equal sign in (24) shows the change in country $H$ relative income (compared to the income of $F$ ) necessary to obtain the Pareto optimal allocation. Given $\sigma>1$, the efficient portfolio has to be such that a real appreciation (welfare based) is associated with an increase in relative spending and income.

The financial market is effectively complete (up to a first order approximation) when there exists a pair $(S, b)$ such that $(23)$ and the second equation in (24) both hold for arbitrary realizations of the relative shocks $\widehat{y}, \widehat{\Psi}, \widehat{k}$. Clearly, the market can only be complete when there are (at most) two relative shocks.

\subsection{Complete markets examples}

We now solve for equilibrium portfolios in economies with just two (relative) shocks. In these economies, markets are effectively complete (perfect spanning).

\subsubsection{Output and iPod shocks}

We start with a situation with just relative supply (output) and iPod shocks $\widehat{y}, \widehat{\Psi}$. The following portfolio $(S, b)$ ensures that $(23)$ and $(24)$ hold for arbitrary realizations of $\widehat{y}$ and $\widehat{\Psi}$ :

$$
S=1 / 2\left[1-\frac{(2 a-1)}{\bar{k}} \frac{(1-1 / \sigma)}{\lambda-1}-\frac{1-\bar{k}}{\bar{k}}\right] ; b=0
$$

Note that the correlation between shocks does not matter for the equilibrium portfolio, as long as the correlation is not perfect (this also holds in the other complete markets examples discussed below). The local equity share depends on three terms: the first term, $1 / 2$, represents the diversification motive in a single-good world with zero labor income, as analyzed by Lucas (1982): in such a world equity portfolios are fully diversified. The second term, $-\frac{1}{2} \frac{(2 a-1)}{\bar{k}} \frac{(1-1 / \sigma)}{\lambda-1}$, represents the hedging of real exchange rate risk, as analyzed, i.a., in Coeurdacier (2005), Kollmann (2006b), Obstfeld (2007) and van Wincoop and Warnock (2006); this term is negative, i.e. it generates foreign equity bias, when the substitution 
elasticity between goods, $\phi$, is (roughly speaking) larger than unity (so that $\lambda>1$ ) ${ }^{6}$; when there is no consumption home bias $(a=1 / 2)$, the real exchange rate is constant and the second term disappears.

The third term, $-\frac{1}{2} \frac{1-\bar{k}}{\bar{k}}$, represents the foreign equity bias in a single-good world with labor income and a constant capital share, so that labor and capital incomes are perfectly positively correlated (see Baxter and Jerman (1997)); in such a world, foreign equity bias emerges as labor income is less closely correlated with foreign equity returns than with domestic returns.

With just supply and iPod shocks, bonds are not useful for the hedging of terms of trade risk, as the latter is hedged using stocks; hence, $b=0$.

Thus, this case shares the difficulties of the previous literature to explain equity home bias. It makes clear that in order to get more realistic portfolios, one needs a shock that eliminates the perfect correlation between relative dividends and the real exchange rate, as well as the perfect correlation between labor and capital incomes. We next analyze such a shock, namely a redistributive shock.

\subsubsection{Output and redistributive shocks}

We now analyze a situation with just relative output and capital share (redistributive) shocks, $\widehat{y}$ and $\hat{k}$. It follows from (23) and (24) that, in this case, the equilibrium portfolio is:

$$
S=1 ; \quad b=\frac{1}{2}[(2 a-1)(1-1 / \sigma)+\lambda-1]
$$

Hence, full equity home bias $(S=1)$ appears for all preference parameters and any stochastic structure of the two shocks. By contrast, the previous literature on portfolio choice in models with labor income and a variable labor/capital share (e.g. Botazzi et al. (1996)) argued that equity home bias only arises when output and the capital share are sufficiently negatively correlated. Note that, in contrast to most of that literature, we here consider a world with multiple goods and the possibility to share risk using bonds.

The predicted full equity home bias reflects the fact that holding local equity insulates household income from capital share shocks; this is important, as the efficient consumption allocation does not depend on those shocks. Intuitively, capital share shocks entail that domestic equity returns are high when domestic labor income is low (and vice-versa); this makes holding local equity attractive. Note that

\footnotetext{
${ }^{6}$ Recall that we assume $\sigma>1$.
} 
this mechanism operates even when the unconditional correlation between labor and capital income is positive (the unconditional correlation is positive when output shocks are sufficiently volatile, compared to capital share shocks.).

More generally, any shock that takes away resources from consumers and redistributes them to firms would have the same effect on portfolios as the capital share shocks discussed in this Section. The working paper version of this paper shows that a model with output shocks and shocks to government purchases generates the same portfolio as the model with output and capital share shocks.

Once capital share shocks have been hedged by holding local equity, the remaining output risk can be hedged using the bond portfolio; this is so because output shocks induce terms of trade movements that affect the difference between the returns on Home and Foreign good bonds. When $S=1$ holds, then a country's net imports equal its net foreign bond income, as can readily seen from the budget constraints (18) and (19). For country $H:\left(P_{H} / p_{F}\right) C_{H}-q y_{H}=(q-1) b$. In an efficient equilibrium, a positive shock to Home output always worsens the Home terms of trade $(q)$; when the elasticity of substitution between $H$ and $F$ goods is high, then Home net imports fall, in an efficient equilibrium. For low substitution elasticities, by contrast, net imports rise ${ }^{7}$. There exists a threshold value of the substitution elasticity between Home and Foreign goods $\phi$ for which net imports are unaffected by output shocks; that threshold is roughly equal to unity-it is given by the value of $\phi$ for which the right-hand side the equation that determines $b$ (see (26)) is zero ${ }^{8}$.

$b$ is positive (negative) when a domestic output increase lowers (raises) net imports. When $\phi$ exceeds the threshold, each country thus goes long in local-good bonds (and short in foreign-good bonds): this ensures that an increase in the local endowment (which lowers the country's terms of trade) triggers a capital loss on the country's bond portfolio, which induces the country to lower its net imports, as prescribed by efficient international risk sharing. By contrast, for low values of $\phi$, the country goes short in local good bonds; the terms of trade worsening that results from a positive domestic output shock then leads to a capital gain that allows the country to finance the efficient increase in its net imports.

Empirically, industrialized countries have a positive (gross) foreign currency position, $F C P>0$ (as

\footnotetext{
${ }^{7}$ For example, it is easy to see that when the substitution elasticity is infinite, then the country that receives a higher output ships a fraction of the additional output to the other country, when there is efficient risk sharing; hence the country that receives the higher output lowers its net imports. When the two goods are imperfect substitutes, then term of trade worsen, which dampens the fall in net imports (the relative price of imports rises).

${ }^{8}$ When $\sigma=1$ the threshold value of is: $\phi=1$.
} 
was discussed above). In the setting with just output and capital share shocks, we have:

$$
F C P \equiv \bar{k}(1-S)-b=-b
$$

The main conclusion is therefore that redistributive shocks provide a strong incentive to hold local equity. However, in a world with just supply and redistributive shocks, the predicted foreign currency position is realistic $(F C P>0)$ only for low substitution elasticities, namely for values of $\phi$ roughly smaller than unity, such that $\lambda<1$ holds (as can be see from (26)). (For $\lambda>1$, by contrast, investors are long in local good bonds and short in foreign good bonds, so that a terms of trade depreciation is associated with a wealth transfer from the country to the rest of the world). Note that $\lambda<1$ implies that a positive shock to a country's output worsens its terms of trade so strongly that the relative value of the country's output, at market prices (qy) drops (see (23)). Such a (relative) "immiserizing growth" effect seems implausible, at least among industrialized economies. We thus conclude that, in the model with just supply and redistributive shocks, $F C P>0$ and realistic valuation effects only obtain for implausible parameter configurations.

\subsection{3 iPod and redistributive shocks}

When there are just iPod and capital share shocks $(\hat{\Psi}, \hat{k})$, the model generates full equity home bias; it furthermore yields a positive foreign currency position (FCP), when $\lambda>1$. The equilibrium portfolio with just $\hat{\Psi}, \hat{k}$ shocks is:

$$
S=1 ; \quad b=-\frac{1}{2}-\frac{1}{2} \frac{(2 a-1)(1-1 / \sigma)}{\lambda-1}
$$

As before, capital share shocks are hedged by holding local equity $(S=1)$. iPod risk is hedged using bonds. The bond position is structured in such a manner that external capital gains/losses track changes in efficient consumption spending induced by iPod shocks. A positive relative iPod shock (increase in $\Psi=$ $\left.\Psi_{H} / \Psi_{F}\right)$ depreciates the Home real exchange rate (welfare based), as: $R \widehat{E R_{W B}}=(2 a-1)(\widehat{q}-\widehat{\Psi})=$ $-\frac{1}{\lambda}(2 a-1) \widehat{\Psi}$; this induces a decrease in relative country $H$ consumption spending (assuming $\sigma>1$; see (24)). Following this relative demand shock, country $H$ terms of trade appreciate when $\lambda>1$, i.e. when the elasticity of substitution is roughly speaking greater than unity (see (23)). When $\lambda>1$ holds, country $H$ thus experiences a decrease in its efficient relative consumption spending, in states of the world in which its terms of trade improve; in order to finance efficient consumption spending, the country 
thus goes short in local-good bonds $(b<0)$; as a result, the gross foreign currency position is positive $(F C P>0)^{9}$.

Hence, a combination of demand and redistributive shocks helps to reproduce the broad facts presented in the introduction: home bias in stocks, and a long position in foreign currency (short position in domestic currency).

\section{Characterization of world equilibrium with incomplete mar- kets}

\subsection{Analytical results}

\subsubsection{Solution method}

Complete markets provide a simple and useful benchmark for analyzing international portfolio behavior. However, the complete markets assumption has some unrealistic implications; for example, it implies that ratios of Home to Foreign marginal utilities of consumption are perfectly correlated with real exchange rates; that prediction is rejected by the data (e.g., Kollmann (1991, 1995, 1996), Backus and Smith (1993)). We now assume that the world economy is subjected to the three (relative) shocks simultaneously, so that markets are incomplete.

The solution methods developed by Coeurdacier (2005), Devereux and Sutherland (2006) and van Wincoop and Tille (2006) allow to compute equilibrium portfolios, in economies with incomplete markets. Those methods solve for portfolio that satisfy a second order accurate approximation of household Euler equations for the four assets:

$$
0=E_{0}\left[m_{i}\left(p_{F}-p_{H}\right)\right]=E_{0}\left[m_{i}\left(\frac{k_{j} p_{j} y_{j}}{p_{S}}-p_{H}\right)\right] \text { for } j=\{H, F\}
$$

where $m_{i}=\frac{U^{\prime}\left(C_{i}\right)}{P_{i}}$ is the marginal utility of household $i$ divided by its CPI. Rewriting (29) in relative

\footnotetext{
${ }^{9}$ Note that the model with just $\hat{\Psi}, \hat{k}$ shocks may generate $b<0$ even when $\lambda<1$ holds. For example, this is the case when $\sigma$ is sufficiently close to unity; then relative efficient consumption spending is essentially unaffected by a positive relative iPod shock; Home terms of trade worsen when $\lambda<1$, and thus, the relative value (at market prices) of the Home endowment drops; hence, the $\mathrm{H}$ household needs to obtain a net external capital gain on its bond portfolio, in order to finance its (essentially) unchanged relative consumption spending. In this case too, the country thus goes short in local good bonds.
} 
terms, we get:

$$
\begin{aligned}
0 & =E_{0}\left[\left(m_{i}-m_{j}\right)\left(\frac{k_{j} p_{j} y_{j}}{p_{S}}-p_{H}\right)\right] \text { for } j=\{H, F\} \\
0 & =E_{0}\left[\left(m_{i}-m_{j}\right)\left(p_{F}-p_{H}\right)\right]
\end{aligned}
$$

(30) can be stated as: $E_{o}(m \cdot E R)=0$, where $m=m_{i}-m_{j}$ is the cross-country difference of stochastic discount factors, while $E R$ is the vector of excess returns on the two stocks and the Foreign bond (relative to the return of the Home-good bond):

$$
E R=\left(\begin{array}{l}
\frac{k_{H} p_{H} y_{H}}{p_{S}}-p_{H} \\
\frac{k_{F} p_{F} y_{F}}{p_{S}}-p_{H} \\
p_{F}-p_{H}
\end{array}\right)
$$

A second-order accurate approximation of this condition is given by $E_{o}(\widehat{m} \widehat{E R})=0$, where $\widehat{m}$ and $\widehat{E R}$ are first order accurate ${ }^{10}$.

The equilibrium portfolio is computed in a two-step approach:

(i) For a given portfolio $(S, b)$, the budget constraint (18), the first-order condition that prescribes equalization of marginal rates of substitution between the two goods to terms of trade, and the goods market clearing conditions $((6),(7))$ are solved for $m$ and $E R$. A linear approximation gives: $\widehat{m}=A(S, b) \xi$ and $\widehat{E R}=B(S, b) \xi$, where $\xi=\left[y_{H}, y_{F}, k_{H}, k_{F}, \Psi_{H}, \Psi_{F}\right]^{\prime}$ is the vector of exogenous variables. $A(S, b)$ and $B(S, b)$ are vectors/matrices (of dimensions $(1 \times 6)$ and $(3 \times 6)$, respectively) that are functions of $S$ and $b$.

(ii) Determination of the values of $S$ and $b$ for which $E_{o}(\widehat{m} \widehat{E R})=0$ holds, i.e. $B(S, b) \Sigma A(S, b)=0$, where $\Sigma=E_{0}\left[\xi \xi^{\prime}\right]$ is the covariance matrix of exogenous disturbances.

\subsubsection{Equilibrium portfolios}

Devereux and Sutherland (2006) provide a closed form solution for the equilibrium portfolio. Under incomplete markets, the portfolio depends on the correlation between shocks. We first focus on the simplest case where the three relative shocks are uncorrelated (Sect. 5.3 extends the analysis to correlated

\footnotetext{
${ }^{10}$ All approximations are taken around the equilibrium of a deterministic economy in which the exogenous variables are set at the mean values assumed in the stochastic model; note that $m=0$ and $E R=0$ in the deterministic economy.
} 
shocks); one can show that then the optimal portfolio is given by:

$$
\begin{aligned}
S & =1-\frac{1}{2 \bar{k}} \frac{2 a(\phi-1) \sigma_{y}^{2} \sigma_{\Psi}^{2}[(2 a-1)(1-1 / \sigma)+\lambda-1]}{2 a(\phi-1)(\lambda-1)\left(\sigma_{y}^{2}+\sigma_{k}^{2}\right) \sigma_{\Psi}^{2}+\sigma_{y}^{2} \sigma_{k}^{2}} \\
b & =\frac{1}{2} \frac{[(2 a-1)(1-1 / \sigma)+\lambda-1]\left[\sigma_{y}^{2}-2 a(\phi-1) \sigma_{\Psi}^{2}\right] \sigma_{k}^{2}}{2 a(\phi-1)(\lambda-1)\left(\sigma_{y}^{2}+\sigma_{k}^{2}\right) \sigma_{\Psi}^{2}+\sigma_{y}^{2} \sigma_{k}^{2}}
\end{aligned}
$$

where $\sigma_{y}=\operatorname{std}(\widehat{y}), \quad \sigma_{\Psi}=\operatorname{std}(\widehat{\Psi})$ and $\sigma_{k}=\operatorname{std}(\widehat{k})$ are the standard deviations of the (relative) supply, iPod and redistributive shocks respectively. Note that eliminating one of the shocks (setting one of the standard deviations to zero) brings us back to the complete markets situations analyzed in the preceding section. The local equity position can be rewritten as:

$$
\begin{aligned}
S= & \frac{1}{2}-\frac{1}{2 \bar{k}} \frac{2 a(2 a-1)(\phi-1)(1-1 / \sigma) \sigma_{y}^{2} \sigma_{\Psi}^{2}}{2 a(\phi-1)(\lambda-1)\left(\sigma_{y}^{2}+\sigma_{k}^{2}\right) \sigma_{\Psi}^{2}+\sigma_{y}^{2} \sigma_{k}^{2}} \\
& +\frac{1}{2 \bar{k}} \frac{\left[2 a(\phi-1)(\lambda-1) \sigma_{\Psi}^{2}+\sigma_{y}^{2}\right] \sigma_{k}^{2}}{2 a(\phi-1)(\lambda-1)\left(\sigma_{y}^{2}+\sigma_{k}^{2}\right) \sigma_{\Psi}^{2}+\sigma_{y}^{2} \sigma_{k}^{2}}-\frac{1-\bar{k}}{2 \bar{k}} .
\end{aligned}
$$

The equity portfolio depends on four terms. The first term $(1 / 2)$ reflects the diversification motive in a single-good world with zero labor income. The second term represents the hedging of real exchange rate risk which we discussed already in the complete market case (see section 4.4.1). Real exchange rate hedging is now more complex, because of the larger number of shocks. The second term tends to generate a foreign equity bias for sufficiently high substitution elasticities $(\phi>1)^{11}$. Again, this term disappears when preferences are identical across countries (no consumption home bias, $a=1 / 2$ ), as then the real exchange rate is constant. The third term comes from the redistributive shock and it tends to induce a Home bias in stocks. When the redistributive shock is sufficiently large (more precisely when $\sigma_{k}^{2}$ is large relative to $\sigma_{\Psi}^{2}$ and $\sigma_{y}^{2}$ ), then there always is equity home bias, $S>1 / 2$. The last term, again, represents the foreign equity bias in a single-good world with labor income, in which the labor share is fixed (so that labor and capital incomes are perfectly positively correlated).

Note also that with a substitution elasticity of unity $(\phi=1)$, full Home bias $(S=1)$ is obtained for all configurations of parameters as long as the variance of the distribution shock $\sigma_{k}^{2}$ is not zero.

The local-good bond position can be rewritten as:

$$
b=-\bar{k}(1-S) \frac{\sigma_{k}^{2}}{\sigma_{\Psi}^{2}}\left[\frac{\sigma_{\Psi}^{2}}{\sigma_{y}^{2}}-\frac{1}{2 a(\phi-1)}\right]
$$

\footnotetext{
${ }^{11}$ Again, for $\phi>1$, foreign stocks give higher returns when the Home (welfare-based) real exchange rate appreciates, leading to some foreign bias in equities.
} 
where $S$ is given by (33).

(34) shows the relative importance of the demand and supply shocks for the structure of the bond portfolio. For a substitution elasticity larger than 1 and interior portfolios $(0<S<1)$, agents go short on local good bonds $(b<0)$ and long on foreign-good bonds, when iPod shocks are large enough relative to supply shocks. Intuitively, a negative iPod shock that deteriorates a country's terms of trade also deteriorates its relative output (evaluated at market prices); the shock can thus be hedged by holding Foreign bonds (whose relative return rises when domestic terms of trade worsen).

In the economy with the three types of shocks, the foreign currency position is:

$$
F C P=(1-S) \bar{k}-b=(1-S) \bar{k}\left\{1+\frac{\sigma_{k}^{2}}{\sigma_{\Psi}^{2}}\left[\frac{\sigma_{\Psi}^{2}}{\sigma_{y}^{2}}-\frac{1}{2 a(\phi-1)}\right]\right\}
$$

which is strictly positive as long as there is no full home bias $(S<1)$ in stocks and supply shocks are not too large compared to the iPod shocks.

\subsection{Quantitative analysis with incomplete markets}

\subsubsection{Calibration}

In this Section, we calibrate the incomplete markets model with supply, demand and redistributive shocks. The mean capital share across G7 countries is $40 \%$, hence we set $\bar{k}=0.4 .{ }^{12}$ We computed standard deviations of annual rates of change for real GDP growth and capital shares, for each G7 countries (19722003). Across the G7 countries, the mean standard deviations of (rates of change of) real GDP and the capital share are $1.91 \%$ and $2.34 \%$, respectively.

Equilibrium portfolios under incomplete markets depend on the standard deviations of the relative supply, capital share and iPod shocks, $y \equiv \frac{y_{H}}{y_{F}}, k \equiv \frac{k_{H}}{k_{F}}$ and $\Psi \equiv \frac{\Psi_{H}}{\Psi_{F}}$. We computed a country's relative real GDP and capital share, compared to a geometric average of the remaining G7 countries' GDPs and the capital shares (1972-2003) $)^{13}$. Relative outputs and capital shares undergo highly persistent fluctuations. The mean value (across G7 countries) of standard deviations of annual growth rate of relative GDPs is 1.59\%. For relative capital shares the corresponding mean standard deviation is $2.39 \%^{14}$. For all countries,

\footnotetext{
${ }^{12}$ We measure a country's capital share as 1-(compensation of employees)/(GDP-indirect taxes), using annual data from OECD National Accounts.

${ }^{13}$ The weights are based on countries' time-averaged shares in G7 nominal GDP.

${ }^{14}$ The standard deviations of relative GDP growth rates for the US, Japan, Germany, France, UK, Italy and Canada are $1.7 \%, 2.1 \%, 1.2 \%, 1.44 \%, 1.5 \%, 1.6 \%$ and $1.5 \%$, respectively. The corresponding standard deviations of growth rates of relative capital shares are $2.1 \%, 2.5 \%, 1.6 \%, 2.0 \%, 3.7 \%, 1.9 \%, 2.8 \%$.
} 
the relative capital share is more volatile than relative GDP. In the calibrated model, we therefore set $\operatorname{std}\left(y_{i}\right)=1.91 \%, \operatorname{std}\left(k_{i}\right)=2.34 \%, \sigma_{y} \equiv \operatorname{std}(\widehat{y})=1.59 \%, \sigma_{k} \equiv \operatorname{std}(\widehat{k})=2.39 \%$.

As mentioned before, iPod shocks can have several interpretations, and their quantification is less easy than that of the other two shocks. Under one interpretation, iPod shocks reflect quality changes and/or changes in the number of varieties produced by a country. Recent empirical evidence at a very disaggregated level by Broda and Weinstein (2007) suggests that quality/varieties changes are an important phenomenon. In the model here, portfolios and other endogenous variables only depend on the relative iPod shock. We experiment with two values for the volatility of relative iPod shocks, $\sigma_{\Psi} \equiv \operatorname{std}(\widehat{\Psi})=1 \%$, and $\sigma_{\Psi}=2 \%$, i.e. in one case the iPod shock is less volatile than relative output, while in the other case, it is slightly more volatile than relative output. We also report results for the case where $\operatorname{std}(\widehat{\Psi})=0$. In that case, there are only supply and capital share shocks, and markets are complete.

Across G7 countries, the mean imports/GDP ratio (1972-2003) is 20\%. Hence, we set $a=0.8$.

The substitution elasticity $\phi$ equals the price elasticity of foreign trade flows. A wide range of empirical estimates of $\phi$ has been reported. Hooper and Marquez (1995) survey a large number of time-series studies that estimated (long run) price elasticities of aggregate trade flows, for the US, Japan, Germany, the UK and Canada; the median estimates (post-Bretton Woods era) for those countries are 0.97, 0.80, 0.57, 0.6, and 1.01, respectively. The median estimate across the five countries is 0.88 . We here consider a range of values of $\phi: \phi=0.6,0.9,1.5,2$. That range encompasses most values of $\phi$ that have been assumed in recent quantitative macro/finance models; see, e.g. Kollmann (2006b), Heathcote and Perri (2002), and Chari et al. (2002) who have set $\phi$ at $0.6,0.9$ and 1.5 respectively.

Estimates of $\sigma$ in the range of 2 (or greater) are common for industrialized countries (e.g., Barrionuevo (1992)); in the quantitative experiments below, the risk aversion parameter is hence set at $\sigma=2$.

Table 1 summarizes the parameter values used in the simulations:

Table 1: Parameter values

\begin{tabular}{|l|l|l|l|l|l|l|}
\hline $\begin{array}{l}\text { substitution } \\
\text { elasticity }\end{array}$ & $\begin{array}{l}\text { risk } \\
\text { aversion }\end{array}$ & $\begin{array}{l}\text { spending share } \\
\text { local goods }\end{array}$ & $\begin{array}{l}\text { mean capital } \\
\text { share }\end{array}$ & $\begin{array}{l}\text { std } \\
\text { relative output }\end{array}$ & $\begin{array}{l}\text { std } \\
\text { relative capital share }\end{array}$ & $\begin{array}{l}\text { std } \\
\text { relative iPod shock }\end{array}$ \\
\hline$\phi$ & $\sigma$ & $a$ & $k$ & $\sigma_{y}$ & $\sigma_{k}$ & $\sigma_{\Psi}$ \\
\hline 0.6 to 2 & 2 & 0.8 & 0.4 & $1.59 \%$ & $2.39 \%$ & 1 to $2 \%$ \\
\hline
\end{tabular}


Numerical results Table 2 reports numerical results. Columns (1)-(2) list the standard deviation of the relative iPod shock and the elasticity of substitution. Columns (3)-(8) show model predictions.

Table 2: Numerical results

\begin{tabular}{|c|c|c|c|c|c|c|c|}
\hline $\begin{array}{l}\text { std } \\
\text { iPod } \\
\sigma_{\Psi}\end{array}$ & $\begin{array}{l}\text { Substitution } \\
\text { elasticity } \\
\phi\end{array}$ & $\begin{array}{l}\text { Local equity } \\
\text { position } \\
S\end{array}$ & $\begin{array}{l}\text { Bond } \\
\text { position } \\
b\end{array}$ & $\begin{array}{l}\text { Foreign } \\
\text { currency position } \\
F C P\end{array}$ & $\begin{array}{l}\text { Correlation } \\
\text { equity } \\
\text { returns }\end{array}$ & $\frac{\operatorname{cov}\left(\widehat{R_{H}}-\widehat{R_{F}}, R E R\right)}{\operatorname{var}\left(\widehat{R_{H}}-\widehat{R_{F}}\right)}$ & $\begin{array}{l}\text { Correlation } \\
\text { (Cons.,RER) }\end{array}$ \\
\hline (1) & (2) & (3) & (4) & (5) & (6) & (7) & (8) \\
\hline 0 & 0.6 & 1.00 & -0.08 & 0.06 & 0.67 & 0.28 & -1.00 \\
\hline $1 \%$ & 0.6 & 0.98 & -0.07 & 0.08 & 0.66 & 0.30 & -0.79 \\
\hline $2 \%$ & 0.6 & 0.95 & -0.08 & 0.10 & 0.62 & 0.35 & -0.53 \\
\hline 0 & 0.9 & 1.00 & 0.03 & -0.03 & 0.69 & 0.10 & -1.00 \\
\hline $1 \%$ & 0.9 & 1.00 & 0.03 & -0.03 & 0.69 & 0.11 & -0.96 \\
\hline $2 \%$ & 0.9 & 1.01 & 0.03 & -0.03 & 0.68 & 0.13 & -0.85 \\
\hline 0 & 1.5 & 1.00 & 0.22 & -0.22 & 0.69 & -0.02 & -1.00 \\
\hline $1 \%$ & 1.5 & 0.92 & 0.14 & -0.11 & 0.69 & -0.05 & -0.60 \\
\hline $2 \%$ & 1.5 & 0.75 & -0.05 & 0.14 & 0.69 & -0.08 & -0.56 \\
\hline 0 & 2 & 1.00 & 0.38 & -0.38 & 0.66 & -0.05 & -1.00 \\
\hline $1 \%$ & 2 & 0.81 & 0.10 & -0.02 & 0.67 & -0.07 & -0.43 \\
\hline $2 \%$ & 2 & 0.60 & -0.21 & 0.37 & 0.66 & -0.05 & -0.53 \\
\hline
\end{tabular}

We report the locally held equity share $(S)$, holdings of local-good bonds $(b)$, and the foreign currency position $(F C P=(1-S) \bar{k}-b)$ (see columns (3)-(5)). In addition, we report three statistics that describe the behavior of equity returns and the real exchange rate (columns (6)-(8)): the cross-country correlation of equity returns ${ }^{15}$; the covariance of the measured real exchange $(\widehat{R E R})$ with the cross-country equity returns differential $\left(\widehat{R_{H}}-\widehat{R_{F}}=k_{H} \widehat{p_{H}} y_{H}-k_{F} \widehat{p_{F}} y_{F}\right)$ normalized by the variance of the returns differential, i.e. $\frac{\operatorname{cov}\left(\widehat{R_{H}}-\widehat{R_{F}}, \widehat{R_{E} R}\right)}{\operatorname{var}\left(\widehat{R_{H}}-\widehat{R_{F}}\right)}$; the correlation between (measured) relative aggregate consumption and the (measured) real exchange rate. The last two statistics are based on CPIs, real exchange rates and aggregate consumption measures that do not take into the account preference of quality changes $(\widehat{\Psi})$; this is again motivated by the fact that empirical CPI and real consumption measures do not (or only very

\footnotetext{
${ }^{15}$ The correlation pertains to equity returns expressed in terms of the Home good.
} 
partially) capture quality/variety changes (see Broda and Weinstein (2007)). Also, purely psychological demand shocks are not reflected in official consumption data.

Markets are complete when there are no iPod shocks $\left(\sigma_{\Psi}=0\right)$. $100 \%$ equity home bias $(S=1)$ is then obtained, and countries hold a long position in local-good bonds if $\phi>1$. In the model versions with $\phi>1$, the long position in home currency is sizable (it amounts to $22 \%$ of expected output, when $\phi=1.5)$. This is just a restatement of the puzzle presented before; with supply shocks and redistributive shocks only, the model is unable to reproduce a long position in foreign currency for an elasticity of substitution larger than 1 . Introducing iPod shocks reduces the equity home bias, and holdings of localgood bonds, when the substitution elasticity exceeds unity. For example, when $\phi=1.5$, and $\sigma_{\Psi}=2 \%$, the model predicts that $75 \%$ of equity is locally owned, and that countries goes short in local-good bonds; the overall foreign good claim is positive, $F C P=0.14$; that value implies that an exogenous unexpected $10 \%$ worsening of a country's terms of trade would generate a capital gain that represents $1.4 \%(=0.10 * 0.14)$ of (expected) output. We think of this calibration as a plausible benchmark case.

Kollmann (2006b) reports external equity liabilities (defined as the sum of portfolio equity and FDI liabilities) of OECD economies, in 2003 (data source: IMF international investment positions database). US foreign equity liabilities amounted to $37 \%$ of US GDP. Among G7 countries, foreign equity liabilities represented between 12\% (Italy) and 78\% (UK) of domestic GDP. Assuming that the domestic capital stock is about 3 times larger than annual GDP, these figures suggest that between $74 \%$ and $96 \%$ of the capital stocks located in G7 countries were owned by local investors, in 2003. The predicted locally held equity share in the three-shocks model is thus broadly consistent with G7 data.

The cross-country correlations of equity returns given in Table 2 range between 0.6 and 0.7 . The model thus matches the high correlation of stock returns across G7 countries, 0.63. ${ }^{16}$ This high correlation reflects the high positive correlation of output and capital share shocks across countries; ${ }^{17}$ it also reflects terms-of-trade movements (Cole and Obstfeld (1991), Pavlova and Rigobon (2004)): a positive output shock at home raises the relative price of the foreign good-it, hence, raises stock returns, in both

\footnotetext{
${ }^{16}$ For each G7 country, we computed the correlation between the Home real equity return and the "foreign" (rest-of G7) equity return, where (as in the theoretical model), all returns are expressed in units of Home GDP. The mean Home-Foreign equity return correlation is 0.63 (based on annual MSCI returns for 1972-1994).

${ }^{17}$ Among the model predictions shown in Table 2, only the cross-country correlation of equity returns depends on the cross-country correlations of output and of the capital share. In accordance with the mean statistics across G7 countries discussed above, we set the standard deviations of output and the capital share in each country at $1.91 \%$ and $2.34 \%$, respectively. The implied cross-country correlations of output and the capital share are 0.65 and 0.47 , respectively.
} 
countries.

The finance literature has shown that real exchange rate fluctuations generate a hedging motive in portfolio choice. van Wincoop and Warnock (2006) discuss a partial equilibrium model, without labor income, in which the only assets are Home and Foreign stocks. In that model, equity home bias is an increasing function of the "covariance-variance ratio" between the real exchange rate $\widehat{R E R}$, on the equity return differential $\widehat{R_{H}}-\widehat{R_{F}}$ discussed above $\left(\frac{\operatorname{cov}\left(\widehat{R_{H}}-\widehat{R_{F}}, \widehat{\operatorname{RE} R}\left(\widehat{R_{H}}-\widehat{R_{F}}\right)\right.}{)}\right.$; when this "covariance-variance ratio" is zero, then equity home bias is zero, i.e. equity portfolios are perfectly diversified: $S=1 / 2$. van Wincoop and Warnock (2006) document that, empirically the covariance-variance ratio is close to zero ${ }^{18}$; they thus conclude that the "portfolio home bias associated with hedging real exchange rate risk is essentially zero" (p.11). Simple general equilibrium models driven by supply shocks (without demand or redistributive shocks) can only generate equity home bias, if the implied "covariance-variance ratio" is much larger than that observed in the data. As discussed above, in the model here, capital share shocks create a powerful motive for holding local equity; those shocks induce equity return fluctuation that are disconnected from real exchange rate movements. Also, in the setting here, bonds can be used for hedging real exchange rate risk. This enables the present model to simultaneously generate a realistic equity home bias, and to generate a covariance-variance ratio that is close to zero (see column (6) in Table 2).

van Wincoop and Warnock (2006) also discuss a model with trade in stocks and in Home and Foreign bonds; when there are neither capital share nor iPod shocks, the degree of equity home bias depends on a covariance-variance ratio based on components of excess equity returns and of the real exchange rate that are orthogonal to exchange rate movements; empirically, that conditional covariance-variance ratio is essentially zero. In the present model, the conditional covariance-variance ratio is exactly zero.

Under complete markets, the risk sharing condition (16) implies that, up to a linear approximation, relative aggregate consumption is perfectly negatively correlated with the (welfare-based) real exchange rate; see Kollmann (1991, 1995), and Backus and Smith (1993). Empirically, the consumption-real exchange correlation is close to zero (mean correlation for G7 countries: 0.04 (1972-2003)).

Incomplete markets break the perfect correlation between relative consumption and the welfare-based real exchange rate; iPod shocks further weaken the link between measured relative consumption and the measured real exchange rate, when empirical CPI and real consumption measures do not (or only par-

\footnotetext{
${ }^{18}$ For the US vis-à-vis 21 other OECD countries, the "covariance-variance ratio" is 0.11 .
} 
tially) capture quality/variety changes. However, in the model here, the predicted correlation between (measured) relative consumption and the (measured) RER remains too large (in absolute value), compared to the data (see Table 2, column (8)). For the specifications where we obtain the most realistic foreign asset positions, the correlation is around -0.5 (for example, when $\phi=1.5$ and $\sigma_{\Psi}=2 \%$, the consumption-real exchange rate correlation is -0.56). So even though we are going in the right direction, we cannot quantitatively reproduce the low consumption-real exchange rate correlation observed in the data.

We have also studied more in detailed how our results vary with the substitution elasticity $\phi$. When the standard deviation of the iPod shock has an intermediate value of $1.5 \%$, our results are quite robust to setting $\phi$ at values in the range up to 4 or 5 , i.e. at values that are much larger than those generally used in macro/finance models (but closer to elasticities often used in the trade literature). The equity home bias never falls below $60 \%$. We have also checked that our results are quite insensitive to changes in the risk aversion coefficient (a higher coefficient of risk aversion raises slightly foreign stock and bond holdings).

\subsection{Correlated shocks}

In this section, we consider model variants with correlated relative shocks. Under complete markets, equilibrium portfolios do not depend on shock correlations. When markets are incomplete, by contrast, the correlation structure affects portfolios (markets remain incomplete, as long as the correlation between shocks is not $100 \%$ ). In what follows, we thus assume a setting with all three shocks (incomplete markets). We first consider a case in which relative supply and redistributive shocks are correlated (but independent of iPod shocks).

\subsubsection{Correlation between supply and redistributive shocks}

In the Handbook of Macroeconomics, Rotemberg and Woodford (1999), report several measures of the correlation between output and the labor share. They conclude that the labor share is weakly countercyclical; in other terms, the capital share is weakly positively correlated with output. ${ }^{19}$ In the model

\footnotetext{
${ }^{19}$ A possible explanation for a procyclical capital share is given by Gali (1999) who argues that, when prices are sticky, productivity shocks reduce labor demand and employment, and raise the labor share, in the short run. This is the mechanism at work in Engel and Matsumoto's (2004) two-country portfolio choice model with monopolistic competition.
} 
here, equilibrium portfolios depend on the correlation between relative (Home versus Foreign) output and the relative capital share. Across G7 countries (1972-2003), the mean correlation between annual growth rates of relative GDP and relative capital shares is about $20 \% \cdot{ }^{20}$ For the US, the correlation is close to zero.

When there is a non-zero correlation between (relative) supply and redistributive shocks, the equilibrium portfolio is given by equation (36) in the Appendix. As in the zero-correlation case, stock holdings can again be decomposed into four terms that capture different diversification/hedging motives, but these terms are now more complex. The real exchange rate hedging motive (see second term in (36)) becomes stronger. Intuitively, the covariance between equity returns and output is higher when output is positively correlated with the capital share; as a result, the covariance between the real exchange rate and equity returns is lower (when $\phi>1$ ), which pushes towards less equity home bias ${ }^{21}$. Also, with a procyclical capital share, wages are more stable, which dampens the incentive to hedge wage fluctuations through the holding of domestic stocks (see the third term in (36)).

This helps to understand why a positive correlation between shocks reduces somewhat the degree of equity home bias, as can be seen from table 3, where we consider model variants in which the correlation between (relative) supply and capital share shocks are set at 0, 0.2 and 0.4, respectively (Table 3 assumes $\phi=1.5$ and $\sigma_{\Psi}=2 \%$; all remaining parameters are set at the same values as in table 2). For example, when the shock correlation is 0.2 (the mean empirical correlation for G7 countries), then $68 \%$ of stocks are held locally (compared to $75 \%$ in the zero-correlation case).

The predicted Foreign Currency Position $(F C P=(1-S) \bar{k}-b)$ remains positive which is consistent with the data. In fact, FCP tends to be larger, the higher the correlation between output and capital share shocks; this mainly reflects the fact that equity home bias is lower when the correlation is higher.

\footnotetext{
${ }^{20}$ The construction of the relative output and capital share series is discussed above. The correlations for the individual G7 countries are: US: -0.04; Japan: 0.05; Germany: 0.27; France: -0.03; UK: 0.22; Italy: 0.75; Canada: 0.44.

${ }^{21}$ Table 3 below shows that the the "covariance-variance ratio" $\frac{\operatorname{cov}\left(\widehat{R_{H}}-\widehat{R_{F}}, R E R\right)}{\operatorname{var}\left(\widehat{R_{H}}-\widehat{R_{F}}\right)}$ is lower, the higher the correlation between the (relative) supply and redistributive shocks.
} 
Table 3: Numerical results: model variants with correlated shocks

\begin{tabular}{|c|c|c|c|c|c|c|}
\hline $\begin{array}{l}\text { correlation } \\
\text { of } \\
\text { shocks }\end{array}$ & $\begin{array}{l}\text { Local equity } \\
\text { position } \\
S\end{array}$ & $\begin{array}{l}\text { Bond } \\
\text { position } \\
b\end{array}$ & $\begin{array}{l}\text { Foreign } \\
\text { currency position } \\
F C P\end{array}$ & $\begin{array}{l}\text { Correlation } \\
\text { equity } \\
\text { returns }\end{array}$ & $\frac{\operatorname{cov}\left(\widehat{R_{H}}-\widehat{R_{F}}, R E R\right)}{\operatorname{var}\left(\widehat{R_{H}}-\widehat{R_{F}}\right)}$ & $\begin{array}{l}\text { Correlation } \\
\text { (Cons.,RER) }\end{array}$ \\
\hline \multicolumn{7}{|c|}{$\frac{\sigma_{y, k}: \text { output/distribution }}{\sigma_{u} \sigma_{k}}$} \\
\hline 0 & 0.75 & -0.05 & 0.14 & 0.69 & -0.09 & -0.56 \\
\hline 0.2 & 0.68 & -0.08 & 0.21 & 0.68 & -0.15 & -0.56 \\
\hline 0.4 & 0.59 & -0.14 & 0.31 & 0.65 & -0.20 & -0.56 \\
\hline \multicolumn{7}{|c|}{$\frac{\sigma_{y, \Psi}}{\sigma_{y} \sigma_{\Psi}}:$ output $/$ iPod } \\
\hline 0 & 0.75 & -0.05 & 0.14 & 0.69 & -0.09 & -0.56 \\
\hline 0.2 & 0.71 & -0.05 & 0.16 & 0.70 & -0.10 & -0.47 \\
\hline 0.4 & 0.66 & -0.05 & 0.18 & 0.70 & -0.12 & -0.37 \\
\hline
\end{tabular}

\subsubsection{Correlation between supply and iPod shocks}

Finally, we consider a setting in which (relative) supply and iPod shocks are correlated. Under the interpretation of iPod shocks as pure preference shocks, there is no reason to think that these two shocks are correlated. However, if iPod shocks represent changes in the quality of goods (or in the number of varieties), one may believe that the two shocks are somewhat related. For example, when labor productivity rises because of human capital accumulation, this could both increase output and the quality of goods (or give an incentives to introduce new varieties). The equilibrium portfolio under correlated supply and iPod shocks is given in the Appendix (equation (38)).

There are no precise empirical estimates of the correlation between output and quality/varieties changes. Broda and Weinstein (2007) report that, for the US, the net creation of product varieties is procyclical and that the destruction of varieties is counter-cyclical. At a highly disaggregated product group level, the correlation between the net rate of creation of product varieties and the growth of consumption and of sales ranges roughly between 0.1 and 0.4 .

In Table 3, we report model prediction for output-iPod shock correlations of $0,0.2$ and $0.4 .^{22}$ It again appears that our main results are robust. A positive correlation between productivity and iPod shocks lowers somewhat the Home bias in stocks but increase the Foreign Currency Position ${ }^{23}$.

\footnotetext{
${ }^{22}$ We again assume $\phi=1.5$ and $\sigma_{\Psi}=2 \%$; and set all remaining parameters are set at the same values as in table 2

${ }^{23}$ The relationship between the output-iPod shock correlation and home bias in stocks is non-monotonic: for higher correlations, $\mathrm{S}$ rises (S converges towards 1 as the correlation approaches unity).
} 


\section{Conclusion}

This paper has shown that a model with supply, demand and redistributive shocks can help to understand the structure of international portfolios and associated valuation effects. This is in contrast to standard models that focus on supply shocks as the main source of uncertainty.

Our analysis could be extended in several directions. It would be interesting to model more closely the relation between goods supply and the capital share. This could, for example, be done by introducing sticky prices. With nominal rigidities, productivity shocks generate a procylical capital share. It would also be interesting to model in greater detail the relation between supply and demand shocks, especially when we interpret the latter as shocks to the quality or the number of variates of traded goods. Here, one might follow Corsetti, Martin and Pesenti (2007) who show that terms of trade react differently to productivity shocks that affect the unit cost of goods production, and to productivity shocks that affect the cost of creating new varieties. One can also speculate that, in a model with imperfect competition, shocks to the degree of competition and to mark-ups would combine the properties of redistributive and relative demand shocks, and thus help to produce realistic international portfolios, as such shocks likewise redistribute income between capital and labor. We leave those extensions for future research. 


\section{References}

[1] Backus, D., and G.W, Smith, 1993, "Consumption and Real Exchange Rates in Dynamic Economies with Non-traded Goods", Journal of International Economics, 35, 297-316.

[2] Barrionuevo, J., 1992, "Asset Prices in the International Economy, " Ph.D. Dissertation, Economics Department, University of Chicago.

[3] Baxter, M. and U. Jermann, 1997, "The international portfolio diversification is worse than you think", American Economic Review, 87, 170-80.

[4] Benigno, G. and C. Thoenissen, 2006, "Consumption and Real Exchange Rates with Incomplete Markets and Non-Traded Goods", Centre for Economic Policy Research, Working paper 5580.

[5] Blanchard, O., F. Giavazzi and F. Sa, 2005, "International Investors, the US Current Account and the Dollar", Brookings Papers on Economic Activity. 1: 2005, 1-65.

[6] Brainard, W., and J. Tobin, 1991, "On the Internationalization of Portfolios", Discussion Paper, Cowles Foundation.

[7] Bottazi, L., P. Pesenti and E. van Wincoop, 1996, "Wages, Profits and the international portfolio puzzle", European Economic Review, 40, 219-254.

[8] Broda, C. and D. Weinstein, 2007, "Product Creation and Destruction: Evidence and Price Implications," Mimeo, Columbia University.

[9] Chan, K., V.M. Covrig and L.K. Ng, 2005, "What Determines the Domestic and Foreign Bias? Evidence from Mutual Fund Equity Allocations Worldwide", Journal of Finance, 60, 1495-1534.

[10] Chari, V.V., P. Kehoe and E. McGrattan, 2002, "Can Sticky Price Models Generate Volatile and Persistent Real Exchange Rates?", Review of Economic Studies, 69, 533-63.

[11] Coeurdacier, N., 2005, "Do Trade Costs in Goods Markets Lead to Home Bias in Equities?", Mimeo, ESSEC. 
[12] Coeurdacier, N. and S. Guibaud, 2005, "A Dynamic Equilibrium Model of Imperfectly Integrated Financial Markets", Working Paper PSE, 2005-24.

[13] Cole, H., M. Obstfeld, 1991, "Commodity trade and international risk sharing: how much do financial markets matter?", Journal of Monetary Economics, 28, 3-24.

[14] Corsetti, G., L. Dedola and S. Leduc, 2007, "International Risk-Sharing and the Transmission of Productivity Shocks, Working Paper", European Central Bank, forthcoming Review of Economic Studies.

[15] Corsetti, G., P. Martin and P. Pesenti, 2007, "Productivity, Terms of Trade, and the 'Home Market Effect"', Journal of International Economics, forthcoming.

[16] Devereux, M. and A. Sutherland, 2006, "Solving for Country Portfolios in Open Economy Macro Models ", Mimeo, UBC.

[17] Engel, C. and A. Matsumoto, 2006, "Portfolio Choice in a Monetary Open-Economy DSGE Model", National Bureau of Economic Research, Working Paper 12214.

[18] French, K. and J. Poterba, 1991, "Investor Diversification and International Equity Markets", American Economic Review, 81, 222-26.

[19] Gali, J., 1999, "Technology, Employment, and the Business Cycle: Do Technology Shocks Explain Aggregate Fluctuations?", American Economic Review, 89, 249-271

[20] Ghironi, F., Lee, J. and A. Rebucci, 2006, "The Valuation Channel of External Adjustment", Mimeo, Boston College.

[21] Gourinchas, P-O and H. Rey, 2005, "International Financial Adjustment", National Bureau of Economic Research, Working Paper 11155

[22] Heathcote, J. and F. Perri, 2004, "Financial Globalization and Real Regionalization", Journal of Economic Theory, 119, 207-243.

[23] Heathcote, J. and F. Perri, 2002, "Financial Autarky and International Business Cycles", Journal of Monetary Economics, 49, 601-627. 
[24] Hooper, P. and J. Marquez, 1995, "Exchange Rates, Prices, and External Adjustment in the United States and Japan". in Kenen, P. (Ed.), Understanding Interdependence. Princeton, Princeton University Press, pp. 107-68.

[25] Julliard, C., 2004, "Human Capital and International Portfolio Choice", Mimeo, Princeton University.

[26] Julliard, C., 2002, "International Portfolio Diversification Is Not Worse Than You Think", Mimeo Princeton University.

[27] Kollmann, R., 2006a, "A Dynamic General Equilibrium Model of International Portfolio Holdings: Comment", Econometrica, 74, 269-273.

[28] Kollmann, R., 2006b, "International Portfolio Equilibrium and the Current Account", Centre for Economic Policy Research, Working Paper 5512.

[29] Kollmann, R., 1996, "Incomplete Asset Markets and the Cross-Country Consumption Correlation Puzzle", Journal of Economic Dynamics and Control, 20, 945-962.

[30] Kollmann, R., 1995, "Consumption, Real Exchange Rates and the Structure of International Asset Markets", Journal of International Money and Finance, 1995, 14, 191-211.

[31] Kollmann, R., 1991, "Essays on International Business Cycles", PhD Dissertation, Economics Department, University of Chicago.

[32] Lane, P., and G.M. Milesi-Ferretti, 2006a, "The External Wealth of Nations Mark II", IMF Working Paper 06-69.

[33] Lane, P., and G.M. Milesi-Ferretti, 2006b, "Europe and Global Imbalances", forthcoming in Economic Policy.

[34] Lane, P., and G.M. Milesi-Ferretti, 2005, "A Global Perspective on External Positions", IIIS Discussion Paper 79, Trinity College Dublin.

[35] Lane, P. and G.M. Milesi-Feretti, 2003, "International Financial Integration", IMF Staff Papers, 50., $82-113$. 
[36] Lane, P. and J. Shambaugh, 2007, Financial Exchange Rates and International Currency Exposures, mimeo.

[37] Lewis, K., 1999, "Explaining Home Bias in Equities and Consumption", Journal of Economic Literature, $37,571-608$.

[38] Lucas, R., 1982, "Interest Rates and Currency Prices in a Two-Country World", Journal of Monetary Economics, 10, 335-359.

[39] Lustig, H. and S. Van Nieuwerburgh, 2005, "The Returns on Human Capital: Good News on Wall Street is Bad News on Main Street", National Bureau of Economic Research, Working Paper 11564.

[40] Martin, P. and H. Rey, 2006, "Globalization and Emerging Markets: With or Without Crash?", American Economic Review December, 96, 1631-51.

[41] Martin, P. and H. Rey, 2004, " Financial Super-Markets: Size Matters for Asset Trade", 2004, Journal of International Economics, 64, 335- 361.

[42] Obstfeld, M., 2006, "International Risk Sharing and the Costs of Trade", Ohlin Lecture, Stockholm School of Economics.

[43] Obstfeld M. and K. Rogoff, 2000, "The Six Major Puzzles in International Macroeconomics: Is There a Common Cause?", NBER Macroeconomics Annual, 339-390.

[44] Pavlova, A. and R. Rigobon, 2004, "Asset Prices and Exchange Rates", Review of Financial Studies, forthcoming.

[45] Rotemberg J. and M. Woodford, 1999, "The Cyclical Behavior of Prices and Costs", in Handbook of Macroeconomics, Elsevier, 1051-1135.

[46] Tille, C., 2005, Financial Integration and the Wealth Effect of Exchange Rate Fluctuations, Federal Reserve Bank of New York Staff Report 226.

[47] Tille, C. and E. van Wincoop, 2007, "International Capital Flows", National Bureau of Economic Research, Working Paper 12856. 
[48] Uppal, R., 1993, "A General Equilibrium Model of International Portfolio Choice", Journal of Finance, 48, 529-553.

[49] van Wincoop, E. and F. Warnock, 2006, "Is Home Bias in Assets Related to Home Bias in Goods?", National Bureau of Economic Research, Working Paper 12728. 


\section{Appendix}

\subsection{Stylized facts on international portfolios}

Table A1: Home bias in equity portfolios.

\begin{tabular}{|c|c|c|c|c|}
\hline Country & $\begin{array}{c}\text { (1) Country's share } \\
\text { in world market } \\
\text { capitalization } \\
(\text { in } \%)\end{array}$ & $\begin{array}{c}\text { (2) Share of } \\
\text { domestic stocks } \\
\text { in the aggregate } \\
\text { portfolio (in } \%)\end{array}$ & $\begin{array}{c}\text { (3) Share of } \\
\text { domestic stocks in } \\
\text { investment funds } \\
\text { portfolios (in \%) }\end{array}$ & $\begin{array}{c}(4) \\
\text { Portfolio } \\
\text { Home Bias } \\
=\log \left(\frac{\text { column } 3}{\text { column } 2}\right) \\
\end{array}$ \\
\hline United-Sates & 47.8 & 88.7 & 85.5 & 0.62 \\
\hline United-Kingdom & 8.1 & 77 & 43.1 & 2.25 \\
\hline Japan & 11.3 & 89.5 & 71.8 & 2.06 \\
\hline France & 4.3 & 79.8 & 55.3 & 2.92 \\
\hline Germany & 4.0 & 61.3 & 33.5 & 2.72 \\
\hline Canada & 2.4 & 84 & 27.0 & 3.55 \\
\hline Italy & 2.2 & 67.3 & 35.4 & 3.42 \\
\hline Switzerland & 2.2 & 45.6 & 21.0 & 3.03 \\
\hline Netherlands & 2.0 & 43.6 & 19.5 & 3.03 \\
\hline Spain & 1.4 & 86 & 36.0 & 4.11 \\
\hline Australia & 1.2 & 71.7 & 18.2 & 4.09 \\
\hline
\end{tabular}

Column 2 measures the share of domestic stocks in countries portfolios in 2001 for the biggest market capitalization. Sources: CPIS data. Column 3 measures the share of domestic stocks in a representative sample of mutual funds, averaged over the period 1999-2000, Source Chan et al. (2005).

Table A2: Currency exposure of international portfolios in 2005 (in percent of country's GDP).

\begin{tabular}{|l|r|r|r|r|}
\hline \multicolumn{1}{|c|}{ Country } & $\begin{array}{c}\text { Net external } \\
\text { position } \\
\text { (in of GDP) }\end{array}$ & $\begin{array}{c}\text { Net domestic } \\
\text { currency position } \\
\text { (in \% of GDP) }\end{array}$ & $\begin{array}{c}\text { Net US dollar } \\
\text { position } \\
\text { (in \% of GDP) }\end{array}$ & $\begin{array}{c}\text { Net other } \\
\text { currencies position } \\
\text { (in \% of GDP) }\end{array}$ \\
\hline \hline China & 12.5 & -28.3 & 29.2 & 11.6 \\
\hline Euro Area & -15.0 & -65.5 & 16.8 & 34.5 \\
\hline Japan & 35.9 & -26.9 & 38.5 & 53.4 \\
\hline United States & -21.5 & $(-74.8)$ & -74.8 & 53.9 \\
\hline
\end{tabular}

Source Lane and Milesi-Feretti (2006b). 


\subsection{Model variants with correlated shocks: equilibrium portfolios}

In the case of a non-zero correlation between relative output and capital share shocks, the equilibrium portfolio is:

$$
\begin{aligned}
S= & \frac{1}{2}-\frac{1}{2 \bar{k}} \frac{2 a(2 a-1)(\phi-1)(1-1 / \sigma) \sigma_{\Psi}^{2}\left(\sigma_{y}^{2}+\sigma_{y, k}\right)}{2 a(\phi-1)(\lambda-1)\left(\sigma_{y}^{2}+2 \sigma_{y, k}+\sigma_{k}^{2}\right) \sigma_{\Psi}^{2}+\sigma_{y}^{2} \sigma_{k}^{2}-\sigma_{y, k}^{2}} \\
& +\frac{1}{2 \bar{k}} \frac{2 a(\phi-1)(\lambda-1) \sigma_{\Psi}^{2}\left(\sigma_{k}^{2}+\sigma_{y, k}\right)+\sigma_{y}^{2} \sigma_{k}^{2}-\sigma_{y, k}^{2}}{2 a(\phi-1)(\lambda-1)\left(\sigma_{y}^{2}+2 \sigma_{y, k}+\sigma_{k}^{2}\right) \sigma_{\Psi}^{2}+\sigma_{y}^{2} \sigma_{k}^{2}-\sigma_{y, k}^{2}}-\frac{1-\bar{k}}{2 \bar{k}} \\
b= & -\bar{k}(1-S) \frac{\sigma_{k}^{2}}{\sigma_{\Psi}^{2}} \frac{1}{1+\frac{\sigma_{y, k}}{\sigma_{y}^{2}}}\left[\frac{\sigma_{\Psi}^{2}}{\sigma_{y}^{2}}\left(1+\frac{\sigma_{y, k}}{\sigma_{k}^{2}}\right)-\frac{1-\left(\frac{\sigma_{y, k}}{\sigma_{y} \sigma_{k}}\right)^{2}}{2 a(\phi-1)}\right]
\end{aligned}
$$

where $\sigma_{y, k}$ is the covariance between $\widehat{y}$ and $\widehat{k}$.

In the case of a non-zero correlation between relative output and iPod shocks, the optimal portfolio is:

$$
\begin{aligned}
S & =1-\frac{1}{2 \bar{k}} \frac{2 a(\phi-1)\left(\sigma_{\Psi}^{2} \sigma_{y}^{2}-\sigma_{y, \Psi}^{2}\right)[(2 a-1)(1-1 / \sigma)+\lambda-1]}{2 a(\phi-1)(\lambda-1)\left(\sigma_{\Psi}^{2}\left(\sigma_{y}^{2}+\sigma_{k}^{2}\right)-\sigma_{y, \Psi}^{2}\right)+\sigma_{y}^{2} \sigma_{k}^{2}-\sigma_{k}^{2} \sigma_{y, \Psi}[\lambda-1+2 a(\phi-1)]} \\
b & =-\bar{k}(1-S) \sigma_{k}^{2}\left[\frac{2 a(\phi-1)\left(\sigma_{\Psi}^{2}+\sigma_{y, \Psi}\right)-\left(\sigma_{y}^{2}+\sigma_{y, \Psi}\right)}{2 a(\phi-1)\left(\sigma_{\Psi}^{2} \sigma_{y}^{2}-\sigma_{y, \Psi}^{2}\right)}\right]
\end{aligned}
$$

where $\sigma_{y, \Psi}$ is the covariance between $\widehat{y}$ and $\widehat{\Psi}$. 